\title{
Visit the EFSUMB website for the latest programme of the forthcoming Euroson Schools
}

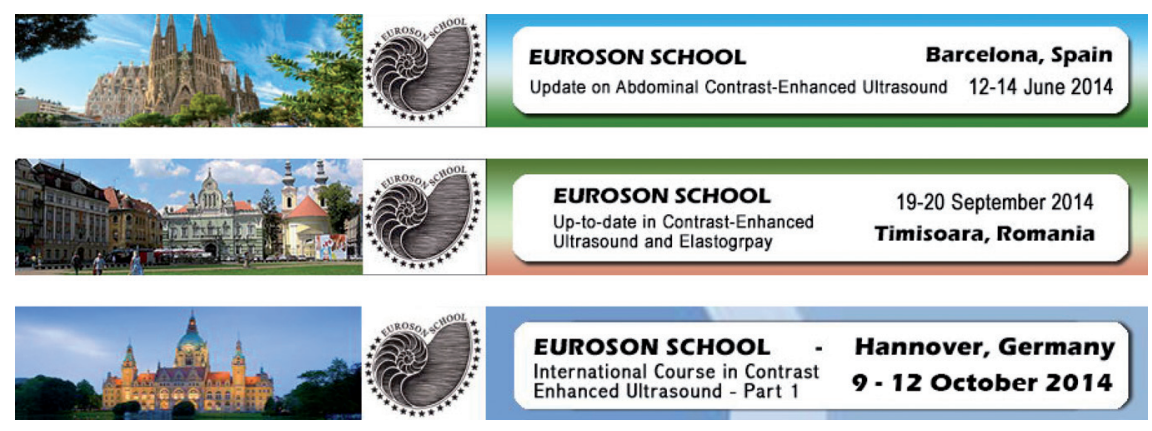

